\title{
Effect of Body Condition Score on Reproductive Performance and Chest Girth of Bali cows in Different Rearing Systems
}

\author{
Sari DAP ${ }^{1}$, Said $\mathrm{S}^{2}, \mathrm{Nahrowi}^{3}$, Priyanto $\mathrm{R}^{4}$, Muladno ${ }^{4 *}$ \\ ${ }^{1}$ Graduate Program in Animal Production and Technology, Faculty of Animal Science, IPB University \\ ${ }^{2}$ Research Center for Biotechnology, National Research and Innovation Agency \\ ${ }^{3}$ Department of Nutrition and Feed Technology, Faculty of Animal Science, IPB University \\ IDepartment of Animal Production and Technology, Faculty of Animal Science, IPB University \\ *Corresponding author: muladno@gmail.com \\ (received 25-08- 2021; revised 12-01-2022; accepted 21-01-2022)
}

\begin{abstract}
ABSTRAK
Sari DAP, Said S, Nahrowi, Priyanto R, Muladno. 2021. Pengaruh body condition score pada performa reproduksi dan lingkar dada sapi Bali pada sistem pemeliharaan berbeda. JITV 26(4):158-166. DOI: http://dx.doi.org/10.14334/jitv.v26i4.2886.

Nutrisi dan sistem pemeliharaan merupakan salah satu faktor utama yang memengaruhi peroduktivitas sapi. Body condition score (BCS) adalah metode yang digunakan untuk menilai status nutrisi dan mengevaluasi sistem pemeliharaan tiap individu ternak. Penelitian ini bertujuan untuk menganalisis pengaruh dan hubungan antara BCS terhadap performa reproduksi dan lingkar dada sapi Bali pada sistem pemeliharaan yang berbeda. Penelitian ini dilakukan di Stasiun Lapang Sekolah Peternakan Rakyat (SL-SPR) Kuamang Abadi, Kabupaten Bungo, Jambi, Indonesia. Materi yang digunakan adalah 62 ekor sapi bali dengan kategori nilai BCS 2, 3 dan (skala 1-5) yang dipelihara pada sistem intensif semi-intensif dan ekstensif. Penelitian dilakukan dengan metode survey dan observasi langsung. Variabel yang diamati adalah BCS, jarak beranak (CI), masa kosong (DO), service per conception (S/C) dan lingkar dada (LD). Data dianalisis menggunakan analisis korelasi dan regresi sederhana dengan software SPSS, kemudian dianalisis secara deskriptif. Hasil penelitian menunjukkan bahwa BCS sapi bali pada sistem pemeliharaan yang berbeda tidak berpengaruh terhadap CI, DO, S/C dan LD. BCS memiliki koefisien korelasi (r) yang lemah terhadap kinerja reproduksi CI, DO, dan S/C masing-masing 0,09; 0,09 dan 0,08. BCS dan LD memiliki hubungan yang signifikan dengan koefisien korelasi (r) sebesar 0,53. Hasil penelitian disimpulkan bahwa BCS memiliki hubungan positif terhadap CI, DO, S/C dan LD. BCS tidak dapat digunakan sebagai satu-satunya indikator untuk menilai kinerja reproduksi sapi bali yang dipelihara pada sistem pemeliharaan yang berbeda.
\end{abstract}

Kata Kunci: Sapi bali, Body condition score, Lingkar dada, Kinerja reproduksi

\section{ABSTRACT}

Sari DAP, Said S, Nahrowi, Priyanto R, Muladno. Effect of body condition score on reproductive performance and chest girth of Bali cattle in different rearing systems. JITV 26(4):158-166. DOI: http://dx.doi.org/10.14334/jitv.v26i4.2886.

Nutrition and rearing systems are some of the main factors affecting productivity of cows. Body condition score (BCS) is a method used to assess nutritional status and evaluate rearing systems of each animal. This study was done to analyze effect of BCS on reproductive performance and chest girth of Bali cow in different rearing systems. This study was conducted at the Field Station of Sekolah Peternakan Rakyat Kuamang Abadi, Bungo Regency, Jambi, Indonesia. A total of 62 heads of Bali cow with BCS of 2,3, and 4 (scale 1-5) reared on intensive, semi-intensive and extensive systems were used in this study. This study was conducted using survey and direct observation. Variables observed were as follows: BCS, calving interval (CI), days open (DO), service per conception (S/C) and chest girth (CG). Data were analyzed using simple correlation and regression analysis in SPPS, followed by descriptive analysis. Result showed that the BCS of Bali cow in different rearing systems did not affect CI, DO, S/C and CG. BCS had a weak correlation coefficient (r), with the reproductive performance of CI, DO, and S/C at 0.09, 0.09, and 0.08 , respectively. In addition, the relationship between BCS and CG was highly significant, with a correlation coefficient (r) of 0.532. Therefore, BCS had a positive relationship with CI, DO, S/C, and CG. Moreover, BCS cannot be used as the only indicator to assess the reproductive performance of Bali cow in different rearing systems.

Key Words: Bali cow, Body condition score, Chest girth, Reproductive performance

\section{INTRODUCTION}

The increase in beef cattle population influenced by the calf operating system, in which smallholder farmers dominate. Calves can be produced annually if the dam has an optimal production performance. Nutrition and maintenance systems are the main factors affecting the reproductive performance of dams. Inadequate nutrition will affect energy and hormone balance, body condition scores (BCS), and reproductive performance, such as delayed puberty, sexual maturity, and reproductive development (Shin et al. 2015; Bhatta \& Kaphle 2020).

Adequacy of nutrients to support productivity of the dam is closely related to the available energy reserves, which is indicated in the amount of fat in the body. Evaluating the proportion of body fat by 
observing the BCS is a practical way to estimate livestock energy reserves. BCS is a method of assessing body condition of livestock visually based on palpation of body fat deposits under the skin around the base of the tail, spine and hips (Nazhat et al. 2021). Changes in BCS conditions are used as a practical tool to monitor energy balance, nutritional status, physiological conditions, health, and growth rate and as a selection indicator to improve reproductive performance and evaluate maintenance systems (Soares \& Dryden 2011; Cornelius et al. 2014; Torres et al. 2015; Wang et al. 2019; Souissi \& Bouraoui 2020). BCS conditions such as excess fat content in cows tend to cover the reproductive tract, resulting in impaired function of the reproductive organs. On the contrary, low BCS in cows can reduce their ability to synthesize a reproductive hormone that interferes with ovulation.

Bali cattle are a breed of beef cattle, which are kept primarily by smallholder farmers because of their adaptive nature, high fertility, good growth, and high carcass percentage (Purwantara et al. 2012). Bali cattle population contributes $26.9 \%$ per year to national meat demand (Fuah et al. 2020). Bali cattle rearing system in smallholder farmers consists of traditional intensive, semi-intensive, and extensive systems. The absence of records and the limited facilities for smallholder farmers cause Bali cattle productivity to be unmeasurable and uncontrollable; therefore, a simple method to assess cattle productivity, including reproductive and production performance, particularly in the dam as calf producers, is necessary

Relationship between BCS, and reproductive and productive performance has been widely reported in dairy cattle (Oba et al. 2013; Aungier et al. 2014; Gruber et al. 2018) and some crossbred cattle (Budiawan et al. 2015; Dwitarizki et al. 2018; Ervandi et al. 2020), but the information of local cattle raised by small holder farmers such as Bali cattle is limited. This study aims to analyze effect of BCS on reproductive performance. The reproductive performance is measured on the basis of the calving interval (CI), days open (DO), service per conception (S/C) and chest circumference (CC) of Bali cow. This result can be used as basis data for breeders to improve the reproductive performance of Bali cow.

\section{MATERIALS AND METHODS}

\section{Study area}

This research was conducted at the Field Station of Sekolah Peternakan Rakyat Kuamang Abadi, Bungo Regency, Jambi Province, Indonesia. Four villages (Cilodang, Tirta Mulya, Lingga Kuamang, and Sumber Harapan villages) from two districts (Pelepat and Pelepat Ilir) were chosen for data collection. Sampling was conducted on Bali cow owned by smallholder farmers reared in intensive, semi-intensive, and extensive systems in oil palm areas. Bali cow were intensively kept and reared in a pen with cut and carry feeding. The semi-intensive system was carried out by releasing the cattle in the oil palm area from 06:00 a.m. to 5:00 p.m and kept in a pen at night. Meanwhile, cattle raised in extensive systems were released in the palm area without being penned.

\section{Data collection}

The methods used in this study included survey and collecting of primary and secondary data. Primary data were obtained by direct observation and interviews with farmers using a questionnaire, whereas secondary data were obtained from data and information of the inseminator. Sixty-two heads of Bali cows reared in intensive, semi-intensive and extensive systems were used in this study. The Bali cows were selected by random sampling with a minimum once of calving, age of 4-10 years, and BCS of 2-4 (scale 1-5). The number of samples is presented in Table 1 .

The parameters observed in this study includes BCS, reproductive performance (CI, DO, and S/C), and CG. The BCS was measured by observing and palpating the hips and ribs. In addition, BCS measurement in Bali cow used a scale of $1-5(1=$ four or more ribs are very prominent and visible in the abdomen; $2=$ three ribs are visible in the abdoment; $3=$ two ribs are visible in the abdomen; $4=$ one rib visible in the abdomen; $5=$ no ribs are visible in the abdomen) (Soares \& Dryden (2011)

Reproductive performance data were obtained from the owner information and inseminator records. CI was obtained by calculating the difference between the dates of two births (first and second calf and so on) (Titterington et al. 2017). DO was obtained from the number of days after calving to conception (Stadnik et al. 2017). S/C was calculated by dividing the number of mating in a group of cattle by the number of pregnant cattle (Suhendro et al. 2013). CG was measured by wrapping a measuring tape on the chest behind the shoulder, which was in accordance with the National Standardization Agency for Indonesia (SNI 2017) procedure.

\section{Data analysis}

The data were tabulated on Microsoft Excel 2019 and arranged by BCS category based on different maintenance systems. Then, the data were analyzed using analysis of variance to obtain the mean, standard deviation, and significant difference among variables. The relationship between BCS and CI, DO, S/C, and CG was analyzed by correlation analysis and simple regression using SPSS, followed by descriptive analysis. 
Sari et al. Effect of body condition score on reproductive performance and chest girth of Bali cattle in different rearing systems

Table 1. Number of Bali cow samples based on the body condition score (BCS) at Sekolah Peternakan Rakyat (SPR) Kuamang Abadi, Bungo Regency, Jambi Province, Indonesia

\begin{tabular}{ccccc}
\hline \hline \multirow{2}{*}{ BCS } & \multicolumn{3}{c}{ Number of sample (heads) } & Total (heads) \\
\cline { 2 - 4 } & Intensive & Semi-intensive & Extensive & 13 \\
2 & 7 & 3 & 3 & 27 \\
4 & 15 & 9 & 3 & 22 \\
Total (heads) & 11 & 5 & 6 & 62 \\
\hline
\end{tabular}

\section{RESULTS AND DISCUSSION}

\section{Calving interval}

Results showed that the BCS in different rearing systems had no significant effect on the CI value $(P>$ 0.05 , Table 2). Therefore, Bali cow with a BCS of 3 had a shorter CI than those with BCS of 2 and 4 (369.4 \pm 33.8 days). In addition, Bali cow with a BCS of 2, which were reared in semi-intensive systems, had a shorter CI than those reared in intensive and extensive systems. Meanwhile, cow with a BCS of 3 reared in the intensive system had the shortest average CI of $364.7 \pm$ 28.2 days. By contrast, the extensive rearing system extended the CI $(406.3 \pm 70.7$ days $)$. In the BCS 4 category, cows reared in a semi-intensi system had a mean CI of $370.8 \pm 30.4$ days.

In this study, the average CI of Bali cow ranged from 364.7 days to 406.3 days. This result is similar to the average CI of Bali cow in several regions in Indonesia, which ranges from 360.9 days to 457.8 days (Gunawan et al. 2011; Pemayun et al. 2014; Said et al. 2020; Sari et al. 2020). The results showed that BCS and different rearing systems do not significantly affect CI of Bali cow. These results are similar to those of Budiawan et al. (2015) who reported that BCS did not significantly affect Filial Ongole cattle, and those of Tait et al. (2017), who studied Angus and their crosses. Length of CI is strongly influenced by pregnancy and DO. Pires et al. (2013) reported that extended CI tended to incerase BCS of cattle. Dairy cows with a BCS of 3 are more sensitive to oxidative stress (Laubenthal et al. 2017). High BCS can also causes high oxidative stress, resulting in risk for disorders during calving (Gheise et al. 2017). Similarly, cows with a BCS of 4 have longer CI than those with BCS of 2 and 3.

Adequate nutrition before and after parturition is important for subsequent pregnancy. In this study, cows with a BCS of 3, which are kept in an extensive system, had the longest CI of 406.3 days. Cattle reared in extensive systems only rely on forage under oil palm as a source of feed. Hence, they vary in nutrient intake because of different quality and quantities between seasons. This condition causes feed restrictions, particularly in the dry season, causing malnutrition in cows (Gutiérrez et al. 2014). Endrawati et al. (2020) reported that pregnant cows, which are kept under oil palm areas with a single feed of forage, did not meet their nutritional requirements, thus additional nutrients were necessary. Lack of nutrition causes a decrease in body condition, increases post-partum interval to conception, affects ovarian activity and follicular growth, and increases infertility and risk of death in calves (Bindari et al. 2013; Centurión-Castro et al. 2013; Endrawati et al. 2017; Smuts et al. 2019). In addition, weaning time affects length of CI. Sari et al. (2021) reported that cattle reared in grazing areas had a longer weaning time because of the absence of weaning control from the farmer, thereby extending CI.

\section{Days open}

The difference of BCS in Bali cow reared in intensive, semi-intensive and extensive maintenance systems did not show a significant effect on the means of DO $(P>0.05$, Table 3$)$. Bali cow with a BCS of 3 had a shorter DO $(84.4 \pm 33.8$ days $)$ than those with BCS of 2 and 4. In addition, Bali cow with BCS of 2 and 4, which were reared in the semi-intensive system, had the shortest DO, whereas those reared in the intensive system had the longest DO. However, under BCS 3, cattle reared in the intensive system had a shorter DO than those reared in semi-intensive and extensive systems.

In this study, DO of Bali cow ranged from 79.7 days to 121.3 days. These results are not significantly different from DO of Bali cow kept by smallholder farmers as reported by Pian et al. (2020) and Sari et al. (2020), which are 112.5 and 109.2 days, respectively. The average cattle DO in Indonesia ranges from 116.09 days to 149.32 days (Nuryadi \& Wahjuningsih 2011; Setyono et al. 2014; Habaora et al. 2019). On the contrary, the normal range of cattle DO is 60-90 days, which is relatively normal if it exceeds 90 days (Ananda et al. 2019). DO is the number of days from calving to subsequent pregnancy (Stadnik et al. 2017). The results showed that cattle reared in extensive systems had the highest DO value, which was similar to CIs. 
Table 2. Calving interval (days) of Bali cows in various body condition scores (BCS) and different rearing systems at Sekolah Peternakan Rakyat (SPR) Kuamang Abadi, Bungo Regency, Jambi Province, Indonesia

\begin{tabular}{lcccc}
\hline \hline \multirow{2}{*}{ BCS } & \multicolumn{3}{c}{ Rearing system } & \multirow{2}{*}{ Average } \\
\cline { 2 - 4 } & Intensive & Semi-intensive & Extensive & $381.0 \pm 35.6^{\mathrm{x}}$ \\
\hline 2 & $390.0 \pm 42.2^{\mathrm{a}, \mathrm{x}}$ & $365.0 \pm 10.0^{\mathrm{a}, \mathrm{x}}$ & $373.5 \pm 40.3^{\mathrm{a}, \mathrm{x}}$ & $369.4 \pm 33.8^{\mathrm{x}}$ \\
4 & $364.7 \pm 28.2^{\mathrm{a}, \mathrm{x}}$ & $365.0 \pm 22.2^{\mathrm{a}, \mathrm{x}}$ & $406.3 \pm 70.7^{\mathrm{a}, \mathrm{x}}$ & $388.3 \pm 55.4^{\mathrm{x}}$ \\
\hline
\end{tabular}

${ }_{a, b, c, c}$ different superscript letters on the same row indicate significant differences $(P<0.05) .^{x, y, z}$ different superscript letters on the same column indicate significant differences $(P<0.05)$

Table 3. Days open of Bali cows in various body condition scores with different rearing systems at Sekolah Peternakan Rakyat (SPR) Kuamang Abadi, Bungo Regency, Jambi Province, Indonesia

\begin{tabular}{|c|c|c|c|c|}
\hline \multirow{2}{*}{ BCS } & \multicolumn{3}{|c|}{ Rearing system } & \multirow{2}{*}{ Average } \\
\hline & Intensive & Semi-intensive & Extensive & \\
\hline 2 & $105.0 \pm 42.2^{\mathrm{a}, \mathrm{x}}$ & $80.0 \pm 10.0^{\mathrm{a}, \mathrm{x}}$ & $88.5 \pm 40.3^{\mathrm{a}, \mathrm{x}}$ & $95.0 \pm 35.6^{\mathrm{x}}$ \\
\hline 3 & $79.7 \pm 28.2^{\mathrm{a}, \mathrm{x}}$ & $80.0 \pm 22.2^{\mathrm{a}, \mathrm{x}}$ & $121.33 \pm 70.7^{\mathrm{a}, \mathrm{x}}$ & $84.4 \pm 33.8^{x}$ \\
\hline 4 & $112.6 \pm 67.8^{\mathrm{a}, \mathrm{x}}$ & $85.8 \pm 30.4^{\mathrm{a}, \mathrm{x}}$ & $104.1 \pm 49.6^{\mathrm{a}, \mathrm{x}}$ & $103.3 \pm 55.4^{x}$ \\
\hline
\end{tabular}

$\overline{\mathrm{a}, \mathrm{b}, \mathrm{c}}$ different superscript letters on the same row indicate significant differences $(P<0.05) .{ }^{\mathrm{x}, \mathrm{y}, \mathrm{z}}$ different superscript letters on the same column indicate significant differences $(P<0.05)$. $\mathrm{BCS}=$ body condition scores

In the cattle rearing system of smallholder farmers, DO is strongly influenced by postpartum estrus, postpartum mating, and S/C (Agus \& Widi 2018). Postcalving is a critical point because cow body scores will decrease to improve nutrition (Souissi \& Bouraoui 2020). After calving, cows experience uterine involution, which is the recovery phase of ovarian activity to prepare the uterus and other reproductive organs and the endocrine system to start the estrus cycle, normal reproduction, and subsequent pregnancy. Under normal conditions, uterine involution is around 25-50 days after parturition, which is followed by postpartum estrus (Wathes et al. 2011).

Cows with poor body conditions can cause malfunctions of ovarian activity, thereby affecting the next estrus cycle (Pivko et al. 2012). Moreover, cows with low body conditions during breeding might reduce detection rate of estrus, whereas low body condition in the post-calving period might cause anestrus and anovulatory cycles (Dubuc et al. 2012). Postpartum anestrus is due to a negative energy balance caused by a decrease in BCS, which negatively affects the oocytes released after ovulation, thereby reducing the rate of conception to insemination (Nigussie 2018).

Results showed that cattle with a moderate BCS (3) had an average DO, which was faster than those with a lean body score (2) and fat (4). Bali cows with a BCS of 4 (fat) had the highest average DO of 103.3 days (Table 3 ). Some research results strongly suggest a BCS of approximately 3-3.5 in cows to obtain ideal reproductive performance (Souissi \& Bouraoui 2020). Cows with over conditions increased the risk of metabolic disease, and the possibility of getting pregnant in the first conception is low (Nazhat et al. 2021). Bagiarta et al. (2017) stated that the BCS of cattle depends on the rearing purpose; for fattening purposes, high BCS value was desirable, whereas for breeding purposes, the calves suitable BCS is 3 .

Service per conception

Difference in BCS categories of cattle reared in intensive, semi-intensive and extensive maintenance systems did not significantly affect $\mathrm{S} / \mathrm{C}(\mathrm{P}>0.05$, Table 4). Bali cow with BCS of 3 had the smallest S/C of 1.5 \pm 1.4 times. In addition, Bali cow reared in a semiintensive system under the BCS 2, 3, and 4 categories had a mean $\mathrm{S} / \mathrm{C}$ lower than those reared in intensive and extensive rearing systems. In semi-intensive rearing systems, the higher the condition score, the higher the S/C. Moreover, Bali cow with a BCS of 2 which were reared in semi-intensive system, had the lowest $\mathrm{S} / \mathrm{C}$ of $1.0 \pm 0.5$ times, whereas cattle with a BCS of 3 , which were reared in the extensive system had a high S/C of $3.0 \pm 3.5$ times.

$\mathrm{S} / \mathrm{C}$ is a reproductive performance parameter that shows the number of mating needed to produce one pregnancy. The results showed that the mean $\mathrm{S} / \mathrm{C}$ of Bali cow with BCS of 2,3, and 4 ranged from 1.0 to 3.0. The average number of services per conception of Bali cattle in Indonesia ranges between 1.2 to 2.5 (Adrial \& Mokhtar 2014; Haryanto et al. 2015; Galuh et al. 2020). This condition shows that the S/C of Bali cattle is relatively high. Based on the results, BCS in intensive, semi-intensive, and extensive rearing systems, did not show any difference. However, the cattle with a BCS of 
3 had a lower S/C value than those with a BCS of 2 and 4. These results were not significantly different from those of Ervandi et al. (2020) in Brahman cattle. In crossed Ongole cattle (Budiawan et al. 2015), those with a BCS of 2 and 3 had the same S/C value (1.06), whereas those with BCS of 4 had higher S/C value (1.18). Meanwhile, in Simmental crosses (Dwitarizki et al. 2018), cattle with a BCS of 3.5-4.0 had smaller S/C than those with a BCS of 1.5-3.0. Kim \& Jeong (2019) reported that maintaining cows with a BCS of 3 using environmental and nutritional management strategies can improve first service conception, thereby reducing production management costs.

The high $\mathrm{S} / \mathrm{C}$ value of cows in smallholder farms is generally influenced by reproductive management, such as the matting time. Inaccuracy in mating time is usually due to delays in estrus detection caused by a lack of farmer's knowledge or the occurrence of silent heat, thereby causing failure and repeated breeding (Habaora et al. 2019). Silent heat occurs during normal reproductive cycles and ovulation, but it does not show symptoms of estrus because of estrogen hormone, which is released by ovaries. In general, this case often shows thin or fat condition because of the large amount of fat that covers the body (Lim et al. 2015). Delayed conception in the postpartum period will negatively affect the next level of conception and prolong the interval from calving to conception (Nazhat et al. 2021). The number of services per conception also increases as the number of open days increases (Cielava et al. 2017).

Table 4. Service per conception (times) of Bali cows in various body (BCS) condition scores with different rearing systems at Sekolah Peternakan Rakyat (SPR) Kuamang Abadi, Bungo Regency, Jambi Province, Indonesia

\begin{tabular}{lcccc}
\hline \hline & & & & \\
BCS & Rearing system & Average \\
\cline { 2 - 4 } & Intensive & Semi-intensive & Extensive & $1.9 \pm 1.7^{\mathrm{x}}$ \\
\hline 2 & $2.3 \pm 2.0^{\mathrm{a}, \mathrm{x}}$ & $1.0 \pm 0.5^{\mathrm{a}, \mathrm{x}}$ & $1.9 \pm 1.3^{\mathrm{a}, \mathrm{x}}$ & $1.5 \pm 1.4^{\mathrm{x}}$ \\
4 & $1.3 \pm 1.1^{\mathrm{a}, \mathrm{x}}$ & $1.3 \pm 0.6^{\mathrm{a}, \mathrm{x}}$ & $3.0 \pm 3.5^{\mathrm{a}, \mathrm{x}}$ & $2.2 \pm 2.7^{\mathrm{x}}$ \\
\hline
\end{tabular}

$\overline{a, b, c, c}$ different superscript letters on the same row indicate significant differences $(P<0.05) .{ }^{x, y, z}$ different superscript letters on the same column indicate significant differences $(P<0.05)$

Table 5. Chest girth $(\mathrm{cm})$ of Bali cows in various body condition scores $(\mathrm{BCS})$ and different rearing systems at Sekolah Peternakan Rakyat SPR Kuamang Abadi, Bungo Regency, Jambi Province, Indonesia

\begin{tabular}{|c|c|c|c|c|}
\hline \multirow{2}{*}{ BCS } & \multicolumn{3}{|c|}{ Rearing system } & \multirow{2}{*}{ Average } \\
\hline & Intensive & Semi-intensive & Extensive & \\
\hline 2 & $150.6 \pm 7.2^{\mathrm{a}, \mathrm{x}}$ & $154.0 \pm 11.3^{\mathrm{a}, \mathrm{x}}$ & $154.5 \pm 0.7^{\mathrm{a}, \mathrm{x}}$ & $152.1 \pm 7.4^{\mathrm{x}}$ \\
\hline 3 & $160.5 \pm 7.7^{\mathrm{a}, \mathrm{x}}$ & $159.0 \pm 8.7^{\mathrm{a}, \mathrm{x}}$ & $163.3 \pm 3.5^{\mathrm{a}, \mathrm{x}}$ & $160.3 \pm 7.6^{y}$ \\
\hline 4 & $167.2 \pm 5.9^{\mathrm{a}, \mathrm{x}}$ & $158.6 \pm 3.6^{\mathrm{a}, \mathrm{x}}$ & $165.3 \pm 5.8^{\mathrm{a}, \mathrm{x}}$ & $164.7 \pm 6.3^{z}$ \\
\hline
\end{tabular}

Table 6. Result of correlation and regression analysis between body condition score (BCS) and reproductive and chest girth of Bali cow at Sekolah Peternakan Rakyat (SPR) Kuamang Abadi, Bungo Regency, Jambi Province, Indonesia

\begin{tabular}{lccc}
\hline \hline Component & $\mathrm{r}$ & $\mathrm{R}^{2}(\%)$ & Regression equation \\
\hline Relationship between BCS and CI & 0.09 & 0.9 & $\mathrm{Y}=360.39+5.719 \mathrm{X}$ \\
Relationship between BCS and DO & 0.09 & 0.9 & $\mathrm{Y}=75.396+5.719 \mathrm{X}$ \\
Relationship between BCS and S/C & 0.08 & 0.7 & $\mathrm{Y}=1.107+0.237 \mathrm{X}$ \\
Relationship between BCS and CG & $0.532^{* *}$ & 28.3 & $\mathrm{Y}=141.127+6.058 \mathrm{X}$ \\
\hline
\end{tabular}

$\mathrm{N}=$ the number of sample (heads), $\mathrm{CI}=$ calving interval (days), $\mathrm{DO}=$ days open (days), $\mathrm{S} / \mathrm{C}=$ service per conception (times), $\mathrm{CG}=$ chest girth $(\mathrm{cm}), \mathrm{r}=$ coefficient of correlation; $\mathrm{R}^{2}=$ coefficient determination. $* *$ Correlation is significant at the 0.01 level (2-tailed) 


\section{Chest girth}

Results showed that differences in BCS conditions had a significant effect on the CG $(P<0.05)$ of Bali cow, however no differences in BCS were observed in different rearing systems $(P>0.05$, Table 5$)$. The larger the BCS score, the larger the CG of Bali cow. Under a BCS of 2 and 3, cow reared in the extensive system had a larger $\mathrm{CG}$ than those reared in intensive and semiintensive systems. By contrast, under a BCS of 4, cattle reared in the intensive system had the largest CG, which was $167.2 \pm 5.9 \mathrm{~cm}$.

CG is a strong single variable for predicting body weight in limited rearing systems in smallholder farmers (Katongole et al. 2013). Several studies have reported a high correlation between $\mathrm{CG}$ and body weight, which is generally used to assess productivity in heifers, as an indicator of growth, body calculation, puberty, and date of insemination (Paul et al. 2020). Average CG of Bali cow with a BCS of 2,3, and 4 at SPR Kuamang Abadi ranged from $150.6 \mathrm{~cm}$ to 167.2 $\mathrm{cm}$ (Table 4). This result is greater than the CG of Bali cattle reported by Agung et al. (2018) at Banyumulek Technopark (135.10 cm) and Garantjang et al. (2020) at the Bali Cattle Breeding Station, South Sulawesi $(149.46 \mathrm{~cm})$. Based on the CG measurement, Bali cattle with a body score of 2, 3, and 4 can be included in category I based on the Indonesian National Standard of Bali cattle (BSN 2017).

Based on the observations, BCS had a significant effect on CG. The higher the BSC, the higher the CC. Funding is in line with Manzoor et al. (2017), who reported that $\mathrm{CG}$ increased with the increase of $\mathrm{BCS}$ in Kashmiri cattle. Therefore, BCS can be used as an indicator in assessing livestock productivity. Thorup et al. (2012) reported that BCS and body weight could be important indicators to estimate energy balance and body reserves. Based on variations in BCS in different maintenance systems, no significant difference in CG was observed. However, with regard to the rearing system, the cattle reared in the extensive system have higher CG values than those reared in intensive and semi-intensive rearing systems under a BCS of 2, 3, and 4.

\section{Correlation among BCS, reproductive performance, and CG}

The relationship among BCS, CI, DO, S/C and CG was shown in coefficient of correlation ( $r$ ), coefficient of determination $\left(\mathrm{R}^{2}\right)$, and regression equation (Table $6)$. The results of correlation analysis showed a weak relationship between $\mathrm{BCS}$ and reproductive performance parameters, including CI, DO, and S/C at $0.09,0.09$, and 0.08 , respectively. In addition, several previous studies on PO cattle, Brahman cross, and
Simmental showed a weak correlation between BCS and reproductive performance (Budiawan et al. 2015; Dwitarizki et al. 2018; Ervandi et al. 2020). The weak correlation between BSC and reproductive performance of Bali cow in smallholder farms indicates that BCS cannot be the only major factor determining reproductive performance. The reproductive performance of the dam in smallholder farmers is strongly influenced by reproductive management, such as the weaning and breeding period.

Meanwhile, the relationship between BCS and CG showed a high significant correlation $(P<0.05)$ with the coefficient of correlation (r) of 0.532 . Therefore, BCS can be a good indicator to measure the productivity of Bali cow because it has a high correlation with $\mathrm{CG}$ which is correlated with body weight. In crossbreed dairy cattle, BCS has a high correlation with body weight $(r=0.7)$, but the coefficient of determination $\left(\mathrm{R}^{2}\right)$ is low (Lukuyu et al. 2016). Verbeek et al. (2012) and Kenyon et al. (2014) reported a positive linear relationship between BCS and CG in the ewe. However, Mchugh et al. (2019) argued that body's energy reserves were not dependent on the size of the skeleton. Furthermore, Van Burgel et al. (2011) reported a weak positive relationship between BCS and CG in ruminants because CG was strongly influenced by rumen volume, which affected stomach contents.

\section{CONCLUSION}

Based on the results, BCS has a positive correlation with $\mathrm{CI}, \mathrm{DO}, \mathrm{S} / \mathrm{C}$ and $\mathrm{CG}$ but it has no significant effect on $\mathrm{CI}, \mathrm{DO}$, and $\mathrm{S} / \mathrm{C}$ in Bali cow reared in intensive, semi-intensive and extensive rearing systems. BCS can be used as an indicator to measure production performance through $\mathrm{CG}$, but it cannot be used to assess reproductive performance of Bali cow.

\section{ACKNOWLEDGMENT}

This research was funded by the Program Magister menuju Doktor untuk Sarjana Unggul (PMDSU) project number 1/E1/KP.PTNBH/2021 from the Ministry of Education and Culture, Directorate General of Higher Education, Republic of Indonesia. The authors would like to extend gratitude to SPR Kuamang Abadi for the help and assistance with data support and collection during the research.

\section{REFERENCES}

Adrial, Mokhtar M. 2014. Increasing reproduction performance of Bali cows through improvement of rearing technology in Tidal Swamp of Pulau Pisau District, Central Kalimantan Province. Proceeding of 
Seminar Nasional Teknologi Peternakan dan Veteriner. Bogor (Indones): Indonesian Center of Animal Research and Development. p. 66-72.

Agung P, Putra W, Anwar S, Wulandari A. 2018. Body weight estimation of Bali cattle in Banyumulek Techno Park, West Nusa Tenggara using several morphometric parameters. Bul Peternak. 42:20-25. DOI:10.21059/buletinpeternak.v42i1.29840.

Agus A, Widi T. 2018. Current situation and future prospects for beef cattle production in Indonesia - A review. Asian-Australasian J Anim Sci. 31:976-983. DOI: 10.5713/ajas.18.0233.

Ananda H, Wurlina, Hidajati N, Hariadi M, Samik A, Restiadi T. 2019. Relationship between age with interval calving, days open, and service per conseption of Friesian Holstein (FH) cow. Ovozoa. 8:94-99.

Aungier S, Roche J, Diskin M, Crowe M. 2014. Risk factors that affect reproductive target achievement in fertile dairy cows. J Dairy Sci. 97:3472-3487. DOI: 10.3168/jds.2013-7404.

Bagiarta I, Mudita G, Rono R, Lindawati S. 2017. Dimensi tubuh sapi Bali di Unit Pelaksana Teknis Pembibitan sapi Bali Sobangan. Peternak Trop. 5:181-188.

Bhatta B, Kaphle K. 2020. Nutrition and reproductive underperformance of cattle in Nepal: A short review. Int J Vet Sci Anim Husb. 5:83-86.

Bindari Y, Shrestha S, Shrestha N, Gaire T. 2013. Effects of Nutrition on Haematology of Rabbits : a Review. Adv Appl Sci Res. 4:421-429.

[BSN] Badan Stadardisasi Nasional. 2017. Bibit Sapi Potong Bagian 4 : Bali. Jakarta (Indones): Badan Standardisasi Nasional.

Budiawan A, Ihsan M, Wahjuningsih S. 2015. Hubungan body condition score terhadap service per conception dan calving interval sapi potong Peranakan Ongole di Kecamatan Babat Kabupaten Lamongan. J Ternak Trop. 16:34-40.

Van Burgel A, Oldham C, Behrendt R, Curnow M, Gordon D, Thompson A. 2011. The merit of condition score and fat score as alternatives to liveweight for managing the nutrition of ewes. Anim Prod Sci. 51:834-841.

Centurión-Castro F, Orihuela-Porcayo J, Aké-López R, Magaña-Monforte J, Montes-Pérez R, Segura-Correa J. 2013. Effect of body condition score on estrus and ovarian function characteristics of synchronized beefmaster cows. Trop Subtrop Agroecosystems. 16:193199.

Cielava L, Jonkus D, Paura L. 2017. Number of services per conseption and its relationship with dairy cow productive and reproductive traits. Res Rural Dev. 2:67-73. DOI: $10.22616 /$ rrd.23.2017.051

Cornelius M, Jacobson C, Besier R. 2014. Body condition score as a selection tool for targeted selective treatmentbased nematode control strategies in Merino ewes. Vet
Parasitol.

206:173-181

DOI:

10.1016/j.vetpar.2014.10.031

Dubuc J, Duffield T, Leslie K, Walton J, LeBlanc S. 2012. Risk factors and effects of postpartum anovulation in dairy cows. J Dairy Sci. 95:1845-1854. DOI: 10.3168/jds.2011-4781.

Dwitarizki N, Achadri Y, Tyasari F. 2018. Pengaruh body condition score terhadap service per conception dan gangguan reproduksi pada sapi Peranakan Ongole dan Simmental. Agronomika. 12:140-146.

Endrawati E, Suhartanto B, Baliarti E. 2017. Nutrient adequacy of Bali cattle fed only forage derived from palm oil plantation in Riau Indonesia. Proceeding of $7^{\text {th }}$ International Seminar on Tropical Animal Production. Yogyakarta (Indones): Gadjah University. p. 830-834.

Endrawati E, Panjono, Suhartanto B, Baliarti E. 2020. Consumption and body weight of Bali cows fed only forage from a palm oil plantation under Indonesian tropical environmental conditions. Pakistan J Nutr. 19:86-90. DOI: 10.3923/pjn.2020.86.90.

Ervandi M, Ihsan M, Wahjuningsih S, Yekti A, Susilawati T. 2020. Relationship between body condition score on the service per conception and conception rate of Brahman Cross cows. J Ilm Ilmu-Ilmu Peternak. 30:80-85. DOI: 10.21776/ub.jiip.2020.030.01.08.

Fuah A, Yani A, Priyanto R, Purwanto B, Abdullah L, Riwukore J, Habaora F. 2020. Analysis of the development of Bali cattle population in agriculture ecosystem of Timor Island using system dynamics. Anim Prod. 22:105-117. DOI: 10.20884/1.jap.2020.22.2.45.

Galuh R, Ardika I, Artiningsih R. 2020. Pengaruh perbedaan pejantan sebagai sumber semen terhadap performans reprduksi sapi Bali di Sentra Pembibitan Sapi Bali Sobangan. J Trop Anim Sci. 2:262-2738.

Garantjang S, Ako A, Syawal S, Yuliati F, Hatta M, Talib C. 2020. Body weight and morphometrics of Bali cattle at people breeding station and non breeding station areas. IOP Conf Ser Earth Environ Sci. 492: p. 012037. DOI: 10.1088/1755-1315/492/1/012037.

Gheise N, Riasi A, Shahneh A, Celi P, Ghoreishi S. 2017. Effect of pre-calving body condition score and previous lactation on BCS change, blood metabolites, oxidative stress and milk production in Holstein dairy cows. Ital J Anim Sci. 16:474-483. DOI: 10.1080/1828051X.2017.1290507.

Gruber L, Ledinek M, Steininger F, Fuerst-Waltl B, Zottl K, Royer M, Krimberger K, Mayerhofer M, Egger-Danner C. 2018. Body weight prediction using body size measurements in Fleckvieh, Holstein, and Brown Swiss dairy cows in lactation and dry periods. Arch Anim Breed. 61:413-424. DOI: 10.5194/aab-61-413-2018.

Gunawan A, Sari R, Parwoto Y, Uddin MJ. 2011. Non genetic factors effect on reproductive performance and preweaning mortality from artificially and naturally 
bred in Bali cattle. J Indones Trop Anim Agric. 36:8390. DOI: 10.14710/jitaa.36.2.83-90.

Gutiérrez V, Espasandín A, Machado P, Bielli A, Genovese P, Carriquiry M. 2014. Effects of calf early nutrition on muscle fiber characteristics and gene expression. Livest Sci. 167:408-416. DOI: 10.1016/j.livsci.2014.07.010.

Habaora F, Fuah A, Abdullah L, Priyanto R, Yani A, Purwanto B. 2019. Reproduction performance of Bali cattle on agroecosystem in Timor Island. J Trop Anim Prod. $20: 141-156$ 10.21776/ub.jtapro.2019.020.02.7

Haryanto D, Hartono M, Surharyati S. 2015. Some factors influences service per conception of Bali cattles in Pringsewu Regency. J Ilm Peternak Terpadu. 3:145150.

Katongole CB, Mpairwe D, Bareeba FB, Mukasa-mugerwa E, Ebong C. 2013. Predicting body weight from heart girth, height at withers and body condition score in Bos indicus cattle bulls of Uganda. Livestock Research for Rural Development. 25. h

Kenyon P, Maloney S, Blache D. 2014. Review of sheep body condition score in relation to production characteristics. New Zeal J Agric Res. 57:38-64. DOI: 10.1080/00288233.2013.857698.

Kim I, Jeong J. 2019. Risk factors limiting first service conception rate in dairy cows and their economic impact. Asian-Australasian J Anim Sci. 32:519-526. DOI: 10.5713 /ajas.18.0296.

Laubenthal L, Ruda L, Sultana N, Winkler J, Rehage J, Meyer U, Dänicke S, Sauerwein H, Häussler S. 2017. Effect of increasing body condition on oxidative stress and mitochondrial biogenesis in subcutaneous adipose tissue depot of nonlactating dairy cows. J Dairy Sci. 100:4976-4986. DOI: 10.3168/jds.2016-12356.

Lim H, Yoon H, Im H, Park J, Cho Y, Jeong Y, Ki K, Im S. 2015. Survey on the incidence of reproductive disorders in dairy cattle. J Anim Reprod Biotechnol. 30:59-64. DOI: 10.12750/jet.2015.30.1.59.

Lukuyu M, Gibson J, Savage D, Duncan A, Mujibi F, Okeyo A. 2016. Use of body linear measurements to estimate liveweight of crossbred dairy cattle in smallholder farms in Kenya. Springerplus. 5:1-14. DOI: 10.1186/s40064016-1698-3.

Manzoor A, Patoo R, Khursheed A, Nazir T, Afzal P. 2017. Seasonal variation in body condition score and morphometry with age of crossbred cattle at an organized farm in Kashmir Valley. Int $\mathbf{J}$ Livest Res. 7:126-133. DOI: 10.5455/ijlr.20170620075903.

Mchugh N, Mcgovern F, Creighton P, Pabiou T, Mcdermott K, Wall E, Berry D. 2019. Mean difference in liveweight per incremental difference in body condition score estimated in multiple sheep breeds and crossbreds. Animal. $13: 549-553$

DOI: $10.1017 / \mathrm{S} 1751731118002148$.

Nazhat SA, Aziz A, Zabuli J, Rahmati S. 2021. Importance of body condition scoring in reproductive performance of dairy cows: A Review. Open J Vet Med. 11:272-288. DOI: 10.4236/ojvm.2021.117018.

Nigussie T. 2018. A Review on the role of energy balance on reproduction of dairy cow. J Dairy Res Technol. 1:1-9. DOI: $10.24966 /$ drt-9315/100003.

Nuryadi, Wahjuningsih S. 2011. Penampilan reproduksi sapi peranakan Ongole dan peranakan Limousin di Kabupaten Malang. J Ternak Trop. 12:76-81.

Oba M, Miyashita S, Nishii R, Koiwa M, Koyama H, Ambrose D, Dochi O. 2013. Short communication: Effects of serum obtained from dairy cows with low or high body condition score on in vitro embryo development. J Dairy Sci. 96:1668-1671. DOI: 10.3168/jds.2012-5886.

Paul A, Mondal S, Kumar S, Kumari T. 2020. Body condition scoring in dairy cows - A conceptual and systematic review. Indian J Anim Res. 54:929-935. DOI: 10.18805/ijar.B-3859.

Pemayun T, Putra S, Puger W. 2014. Reproduction performance of Bali cattle on three strata forage system. J Kedokt Hewan. vol 8:61-63. DOI: 10.21157/j.ked.hewan.v8i1.1262.

Pian A, Tophianong T, Gaina C. 2020. Penampilan reproduksi sapi Bali pada sistem pemeliharaan semi intensif. J Vet Nusant. 3:18-31.

Pires J, Delavaud C, Faulconnier Y, Pomiès D, Chilliard Y. 2013. Effects of body condition score at calving on indicators of fat and protein mobilization of periparturient Holstein-Friesian cows. J Dairy Sci. 96:6423-6439. DOI: 10.3168/jds.2013-6801.

Pivko J, Makarevich AV, Kubovicova E, Ostro O, Hegedusova Z, Louda F. 2012. Histopathological alterations in the antral ovarian follicles in dairy cows with a tendency to emaciation. Histology and histopathology. 27: 1211-1217. DOI: 10.14670/HH27.1211.

Purwantara B, Noor RR, Andersson G, Rodriguez-Martinez H. 2012. Banteng and Bali cattle in Indonesia: Status and forecasts. Reprod Domest Anim. 47:2-6. DOI: 10.1111/j.1439-0531.2011.01956.x.

Said S, Putra W, Muzawar M, Kantong S. 2020. Selection of Bali cattle based on birth weight and calving interval records at West Nusa Tenggara Province of Indonesia. J Indones Trop Anim Agric. 45:15-27. DOI: 10.14710/jitaa.45.1.15-27

Sari D, Muladno, Said S. 2020. Potential and reproductive performance of female Bali cattle for supporting breeding business at Field Station of Sekolah Peternakan Rakyat. J Ilmu Produksi dan Teknol Has Peternak. 8:80-85. DOI: 10.29244/jipthp.8.2.80-85

Sari D, Muladno, Said S, Nahrowi, Priyanto R. 2021. Effect of parity on the reproductive performance of Bali cattle at different maintenance systems in Field Station of Sekolah Peternakan Rakyat. IOP Conf Ser Earth Environ Sci. p. 788. DOI: 10.1088/17551315/788/1/012133 
Setyono A, Isnaini N, Wahjuningsih S. 2014. Reproduction performance of Limousin crossnainibreed in Tanggunggunung district tulungagung regency. J Trop Anim Prod. 15:1-8.

Shin E, Jeong J, Choi I, Kang H, Hur T, Jung Y, Kim I. 2015. Relationships among ketosis, serum metabolites, body condition, and reproductive outcomes in dairy cows. Theriogenology. $\quad 84: 252-260$.

DOI: 10.1016/j.theriogenology.2015.03.014.

Smuts M, Sonya D, Thopmson P, Holm D. 2019. Serum albumin concentration of donor cows as an indicator of developmental competence of oocytes. Theriogenology. 125:184-192.

DOI: 10.1016/j.theriogenology.2018.09.002.

Soares FS, Dryden GML. 2011. A body condition scoring system for bali cattle. Asian-Australasian J Anim Sci. 24:1587-1594. DOI: 10.5713/ajas.2011.11070.

Souissi W, Bouraoui R. 2020. Relationship between body condition score, milk yield, reproduction, and biochemical parameters in dairyCGows. IntechOpen. p: 1-13.DOI: $10.5772 /$ intechopen. 85343

Stadnik L, Atasever S, Ducháček J. 2017. Effects of body condition score and daily milk yield on reproduction traits of Czech Fleckvieh cows. Anim Reprod. 14:1264 1269. DOI: 10.21451/1984-3143-AR944.

Suhendro D, Ciptadi G, Suyadi. 2013. Reproductive performance of Swamp Buffalo (Bubalus Bubalis) in Malang Regency. J Ternak Trop. 14:1-7.

Tait I, Morris S, Kenyon P, Garrick D, Pleasants A, Hickson R. 2017. Effect of cow body condition score on intercalving interval, pregnancy diagnosis, weaning rate and calf weaning weight in beef cattle. In: Proc New Zeal Soc Anim Prod. 77. New Zealand; p. 23-28.

Thorup V, Edwards D, Friggens N. 2012. On-farm estimation of energy balance in dairy cows using only frequent body weight measurements and body condition score. J Dairy Sci. 95:1784-1793. DOI: 10.3168/jds.2011-4631.

Titterington FM, Lively FO, Dawson S, Gordon AW, Morrison SJ. 2017. The effects of breed, month of parturition and sex of progeny on beef cow fertility using calving interval as a measure. Adv Anim Biosci. 8:67-71. DOI: 10.1017/s2040470017001741.

Torres HL, Tineo JO, Raidan FS. 2015. Influência do escore de condição corporal na probabilidade de prenhez em bovinos de corte. Arch Zootec. 64:255-260. DOI: 10.21071/az.v64i247.403.

Verbeek E, Waas J, Oliver M, McLeay L, Ferguson D, Matthews L. 2012. Motivation to obtain a food reward of pregnant ewes in negative energy balance: Behavioural, metabolic and endocrine considerations. Horm Behav. 62:162-172. DOI: 10.1016/j.yhbeh.2012.06.006.

Wang Y, Huo P, Sun Y, Zhang Y. 2019. Effects of body condition score changes during peripartum on the postpartum health and production performance of primiparous dairy cows. Animals. 9:1-15. DOI: 10.3390/ani9121159.

Wathes DC, Cheng Z, Fenwick MA, Fitzpatrick R, Patton J. 2011. Influence of energy balance on the somatotrophic axis and matrix metalloproteinase expression in the endometrium of the postpartum dairy cow. Reproduction. 141:269-281. DOI: 10.1530/REP-100177 . 